\title{
SOCIAL ACCOUNTING \& SOCIAL RESPONSIBILITY REPORTING IN THE JORDANIAN INDUSTRIAL COMPANIES LISTED IN AMMAN STOCK EXCHANGE MARKET
}

This study examines practice of social accounting and the reporting of social responsibility in the industrial Jordanian companies listed in Amman Stock Exchange. As operations of industrial companies have significant impact on the society, they should be accountable to the environment, and members of societies in which they operate. The method adopted to figure out the state of current social accounting and reporting practices was carried out by analyzing the annual reports of 30 randomly selected Jordanian industrial companies for the year 2016. The study found that $73 \%$ of industrial companies in Jordan are disclosing their activities of social responsibility in the annual reports. This study also found that $50 \%$ of these companies use the director's reports as the main outlet for disclosing their activities related to social responsibility, $36 \%$ companies use the corporate social responsibility report and finally $14 \%$ are use the notes or schedule to financial statement to inform general people about their commitment to social responsibility. The study recommended that as there are many types and techniques of reporting, the Jordanian securities commission, as a government $r$ gulatory entity, should work on establishing uniformity for disclosing social accounting reports, and the outlet for such disclosure should be clearly specified.

Key words: Amman stock exchange market, corporate social responsibility, social responsibility reporting, Jordanian industrial companies

${ }^{*}$ Dr. Z. AL-Hawatmah, Department of Accounting, Al-Zaytoonah University, Amman, Jordan (E-mail: Zaid73@hotmail.com).

** Dr. O. S. Shaban, Department of Accounting, A1-Zaytoonah University, Amman, Jordan (E-mail: drosama@zuj.edu.jo).

The paper was received on January $8^{\text {th }}, 2018$. It was accepted for publication on June $10^{\text {th }}, 2018$. 


\section{Introduction}

Companies in general and industrial companies in particular are responsible for the environment in which it operates. If members of the society are responsible for their behavior, companies also bear the same responsibility. Management should accept and report its accountability of its operations to the environment and to the members of the society. The commitment to such accountability should be reflected in the financial reports disclosed by the end of each financial year.

The concept of social responsibility requires that companies causing environmental degradation should compensate the society to ensure that members of the society continue to access quality air, water and all natural resources in the environment. However, the economic position of the company should pass the social responsibility test. The aim of such test is to have an informed judgment of the social contribution of these companies. The social responsibility test involves identification, measurement, and description of the social contribution information in a conventional financial manner.

In the 1980s, the focus on social and environmental issues shifted from mere disclosure of workers' information and added value to the need to disclose environmental information, whether through annual financial reports or through other means of disclosure (Nehme \& SALAMA, 2016). We posit that since companies succeeded in delivering adequate and sufficient information about the efficiency of financial or economic performance, they can also succeed in communicating information about the efficiency of the economic unit in meeting its social responsibilities, especially in the field of environmental pollution control.

Many studies have discussed corporate social reporting and objectives from one or two dimensions. Mostly these dimensions discussed the environmental contribution. They concentrated on the environmental factors affecting the accounting disclosure in order to determine the extent and degree of social accounting disclosure required. These researches mostly used five environmental factors to explain the differences in accounting disclosure requirements; the degree of economic development, type of economic, size of the stock market, stock market activities, and dividend distribution. Jahan (2010) has used five areas in which corporate social objectives may be found and each area of contribution of social activities may be measured and reported. The current research is going to use the same areas of contributions used by Jahan, but the research sample will be measured on the Jordanian industrial companies instead of the Indian companies used by Jahan. Further, we are going to analyze the amounts paid as type of donations or compensation to the local community. These amounts will be transformed into a percentage taken out of either net sales or owner's net equity. The aim of such calculations is to make a comparison between these amounts 
paid in order to find a relationship or a determinant of according to which bases these amount was paid.

The main objective of the current study is to identify and explain the main aspects of the social accounting practices in the Jordanian industrial companies, its present level of development, and the current social accounting practices followed in these industries. Both the scope and type of social responsibility reporting of each of the sample industrial companies is going to be analyzed in order to find out the latest social accounting and reporting practices followed by these industries.

The importance of the study stems from the importance of social accounting or environmental to governments and members of societies in which industrial companies are functioning. Knowing the current social accounting practices followed in these industries may help the decision makers in taking the right decision related either to the development of their business opinion or potential investment.

The Jordan Times in its 17th May 2017 edition has published an article describing the importance of corporate social responsibility on business, opining, "Corporate social responsibility has become an important business element that aims at increasing the social contribution of businesses, regardless of their type, size or location. It has become one of the most important factors that determine how different stakeholders judge, react and interact with firms." It also mentioned that Corporate Social Responsibility helps build a strong and harmonious society. It can help resolve social disparities that have increased significantly in recent years, which caused the public to lose trust in many government entities, as well as in businesses, because it sees firms as major entities that fell short on social obligations, and governments as ineffective and having failed to achieve longstanding slogans like "enabling the youth" so they can be effective part of rebuilding the country's economy in efficient and creative ways. The government and civil society organizations need to pressure Jordanian firms that are not already showing social commitment, but to do so, they need to have sound information on what is needed the most, where, and how firms can help address societal needs. Companies on the other hand can perform vigilant analysis of such information and then launch Corporate Social Responsibility projects that cater to the most urgent needs in the society with a just and fair geographical distribution of their projects.

The annual report of the Jordan petroleum refinery company, which one of the Jordanian pioneer Industrial companies, and one of samples of this research study, has disclosed the following information about its corporate social responsibility for the year 2016. It mentioned that "Based on the company's commitment towards the wellbeing of the local community through maintaining healthy environment and realizing the company's environment policy, the company has taken the following steps and activities: 
- Evaluating the tender to treat about (7500) tons of oil sludge resulting from the activities of the different refinery activities.

- Completion of the project of cleaning a number of refinery areas.

- Disposal of dangerous waste resulting from the refinery activities according to the laws and regulations in force.

- Monitoring levels of gas emissions and the environmental situation in the refinery units, loading areas, crude oil area and the surrounding areas and taking corrective actions where necessary.

- Continuation of environmental auditing and monitoring programs in the different refinery areas.

- Monitoring the performance of the industrial wastewater treatment unit.

- Housekeeping of all refinery areas.

The company also reported under the local community service that it has provided services to the local community by extending financial support for educational and religious institutions, charities, and local municipalities in the kingdom through donation to support them in achieving their mission. In 2016, the company donated JD $(482,200)$ which equals about $\$ 679,155$. Another leading company in this field is Jordan Phosphate Mines Company which donated JD 1,859,126, which was also reported in its annual report for the year 2016 under Corporate Social Responsibility Report.

\section{Literature review and previous studies}

In the early $1960 \mathrm{~s}$, the concept of social accounting emerged when social values and expectations gave rise to a debate about the role of business in society. This debate focused on the nature of corporate social responsibility and gave rise to the possibility that this responsibility could be discharged through a method of social responsibility accounting. There have been various attempts made to try and define social accounting and its implication for the society at large in response to concern expressed by many researchers (Jahan, 2010). The social responsibility of the enterprise is concerned with the performance of compulsory and voluntary activities to reduce the negative consequences of its activities and contribute to solving the problems of its environment and community.

Accounting application is still based on an important and implicit assumption at the same time that the project is environmentally and socially irresponsible even if it is state-owned. This shortcoming calls for further research aimed modify the 
accounting role and improve its function by providing information disclosing the social responsibility of the economic unit.

The problem of environmental pollution is one of the most important aspects of social performance and social responsibility of the economic units, and one of the manifestations of external actions that must be made by the accounting measurement within the domain of social accounting. The Jordanian Environmental Protection Law No. 12 of 1995 defines the pollution as" anything that harms the environment, adversely affects its elements, or disrupts its natural balance."

Through the previous information the most important definitions of environmental accounting, we have reached the following:

1. The environmental performance of the establishment is linked to the social performance and its extension, and that the provision of information thereon leads to greater social welfare.

2. The need to change the traditional methods of accounting reporting by identifying and measuring the relationship between firm and the society, the surrounding environment, and the effects of that relationship, and report thereon.

3. Corporate social performance has become part of the accountability of the accountant and his duty towards the parties interested in that performance.

The importance of accountability for the project has increased since the increasing interest in project growth, acceptance of the idea that the project should be assessed on the basis of its contribution of cash flow to the society. The contributions made by many thinkers have attempted to crystallize the role that accountability should play in social responsibility. The most important contributions to corporate social responsibility accounting can be identified by the American Accounting Association Model (A A A). The American Accounting Association has launched a study to figure out the impact of projects on the environment, and to review the reasons that forbidden accountants from not provided the necessary information declaring the impacts of the project on the environment, although they recognize the existence of such impacts. To date, there are no bases or rules for measuring and presenting the social costs of environmental damage arising from project operations for the following reasons:

- Lack of legal standards to protect the environment which originally the firm has committed to by its laws of association and that of course is done to avoid additional costs.

- The difficulty of establishing monetary measures for environmental damage in an objective manner, although this fact does not compensate for the use of non-monetary measures to measure these damages. 
- There is no acceptable basis for distributing social costs of environmental damage to projects.

- The reluctance of many projects to voluntarily disclose the costs associated with environmental damage resulting from their operations, even if such costs can be measured and distributed in an acceptable manner.

Relevant literature has also discussed corporate social responsibility from different point of view. Ahmad et al. (2017) examined the influence of board independence on corporate social responsibility. Byrd et al. (2016) examined the sustainability reporting activities of companies in controversial industries and identified its own controversial social problem. Bhimani et al. (2016) investigated early reporting and alter reporting and its effect on organizational outcomes associated with corporate social responsibility. Wadhwa, (2017) explained how non-financial reporting is becoming part of corporate social responsibility reporting. (Shabana \& Ravlin, 2016) described a multilevel theoretical framework that examined the multiple causes of corporate social responsibility reporting in the social environment of business. Cheng et al. (2015) examined the relationship between the issuance of corporate social responsibility reports and performance, in terms of accounting income, market return, and growth.

\section{Method}

The study was carried out by closely analyzing the Annual Reports of 30 Jordanian industrial companies out of 64 total industrial companies, randomly selected for the financial year 2016 to bring out the latest social accounting and reporting practices of Jordanian industrial companies. The primary data needed for the study objectives were collected through the annual reports of different Jordanian industrial companies. The total listed industrial companies in Jordan are 64 companies. The results of findings analysis were illustrated in tables and figures in order to clearly explain the obtained results. The research study sample were determined using the sample size formula at $95 \%$ confidence level, and $4 \%$ confidence interval, and a total of 30 companies which constitute the study population. Other Data was collected from secondary sources such as articles published by well-known periodicals, books, and dissertations. 


\section{Key results and findings}

Table 1, shows the number and percentages of companies which reported, as well as the number of companies that didn't report its social responsibility in its annual reports collected. It can be noticed that $73 \%$ of the sample companies had reported their social responsibility in their annual reports.

Table 1.

\section{NUMBER AND PERCENTAGES OF COMPANIES WHICH REPORTED OR DIDN'T REPORT ITS SOCIAL RESPONSIBILITY IN ITS ANNUAL REPORTS}

\begin{tabular}{|c|l|c|c|}
\hline No. & Reporting & Number of companies & \% \\
\hline 1 & Reported & 22 & 73 \\
\hline 2 & Not Reported & 8 & 27 \\
\hline & Total & 30 & 100 \\
\hline
\end{tabular}

Source: Jordan Securities Commission/Annual Reports

Table 2 shows the techniques used in reporting the corporate social responsibility by the sample companies. It can be noticed that the major technique of disclosure used by the Jordanian industrial companies was the director's reports $50 \%$. The second vehicle of disclosure used by these companies was the corporate social responsibility report by $36 \%$ of our sample firms. Finally, the third technique of disclosure used by these companies was the notes or schedule to financial statement, which was used by $14 \%$ of the sample firms. It also could be noticed that the Jordanian industrial companies are reporting their social responsibility by using three techniques only, director's reports, corporate social responsibility report, and notes or schedule to financial statement. Jahan, 2010, reported five techniques of social responsibility reporting, three techniques of which we mentioned earlier in addition to annexure to director's report, and separate social report. 
Table 2.

\section{TECHNIQUES USED IN REPORTING THE CORPORATE SOCIAL RESPONSIBILITY BY THE SAMPLE COMPANIES}

\begin{tabular}{|c|l|c|c|}
\hline No. & \multicolumn{1}{|c|}{ Type of disclosure } & No. of companies & $\%$ \\
\hline 1 & Director's Report & 11 & 50 \\
\hline 2 & Notes or Schedule to Financial Statement & 3 & 14 \\
\hline 3 & Corporate Social Responsibility Report & 8 & 36 \\
\hline & Total & 22 & 100 \\
\hline
\end{tabular}

Source: Jordan Securities Commission/Annual Reports

Table 3 shows the percentage of amounts paid by companies that are reporting about its corporate social responsibility in form of Corporate Social Responsibility Report mentioned in Table 2 . The percentage is calculated in two forms, one, as a percentage compared to net owner's equity, second, as a percentage compared to net sales. As it was earlier explained in the introduction that the aim of such calculations is to make a comparison between these amounts paid in order to find a relationship or a determinant of according to which bases these amount was paid.

Table 3.

$$
\begin{aligned}
& \text { DONATION'S PERCENTAGES CALCULATED } \\
& \text { OUT OF NET OWNER'S EQUITY AND OUT OF NET SALES }
\end{aligned}
$$

\begin{tabular}{|c|l|c|c|c|c|c|}
\hline No. & \multicolumn{1}{|c|}{ Name of Company } & $\begin{array}{c}\text { Donations } \\
\text { Amounts } \\
\text { Paid }\end{array}$ & $\begin{array}{c}\text { Net Owner's } \\
\text { Equity }\end{array}$ & $\%$ & Net Sales & $\%$ \\
\hline 1 & Jordan petroleum Refinery Co. & 482,200 & $197,071,070$ & 0.24 & $2,618,174,888$ & 0.02 \\
\hline 2 & Jordan Phosphate Mines Co. & $1,859,126$ & $724,844,000$ & 0.26 & $549,697,000$ & 0.34 \\
\hline 3 & Arab Potash Co. & $10,138,698$ & $892,190,000$ & 1.14 & $527,885,000$ & 1.92 \\
\hline 4 & Jordan Steel Group & 668,628 & $39,913,874$ & 1.68 & $38,103,433$ & 1.75 \\
\hline 5 & Northern Cement Co. & 146,640 & $75,452,977$ & 0.19 & $63,366,846$ & 0.23 \\
\hline 6 & Jordan cement Co.(LAFARGE) & 74,280 & $73,367,047$ & 0.10 & $91,546,594$ & 0.08 \\
\hline 7 & Arab Aluminum & 7,050 & $12,329,123$ & 0.06 & $11,911,406$ & 0.06 \\
\hline 8 & National Chlorine Industries Co. & 8,227 & $10,029,478$ & 0.08 & $8,163,578$ & 0.10 \\
\hline
\end{tabular}

Source: Jordan Securities Commission/Annual Reports 
As can be evidenced from the above table the donation's percentages calculated out of Net Owner's Equity varies between $0.06 \%$ and $1.68 \%$. Figures 1 and 2 illustrate the outcomes of these percentages.

Figure 1 .

\section{DONATION'S PERCENTAGES CALCULATED \\ OUT OF NET OWNER'S EQUITY}

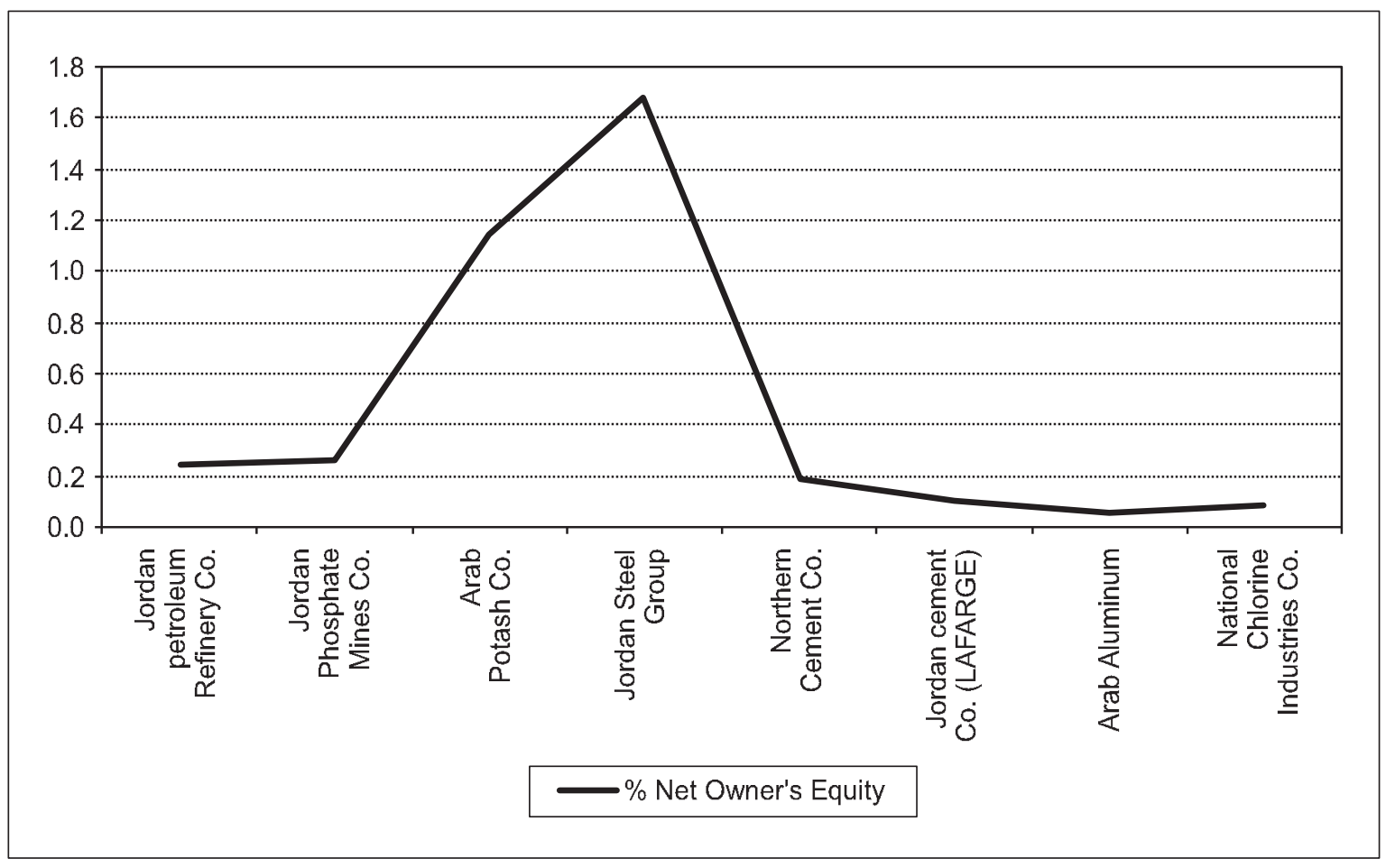


Figure 2.

DONATION'S PERCENTAGES CALCULATED OUT OF NET SALES

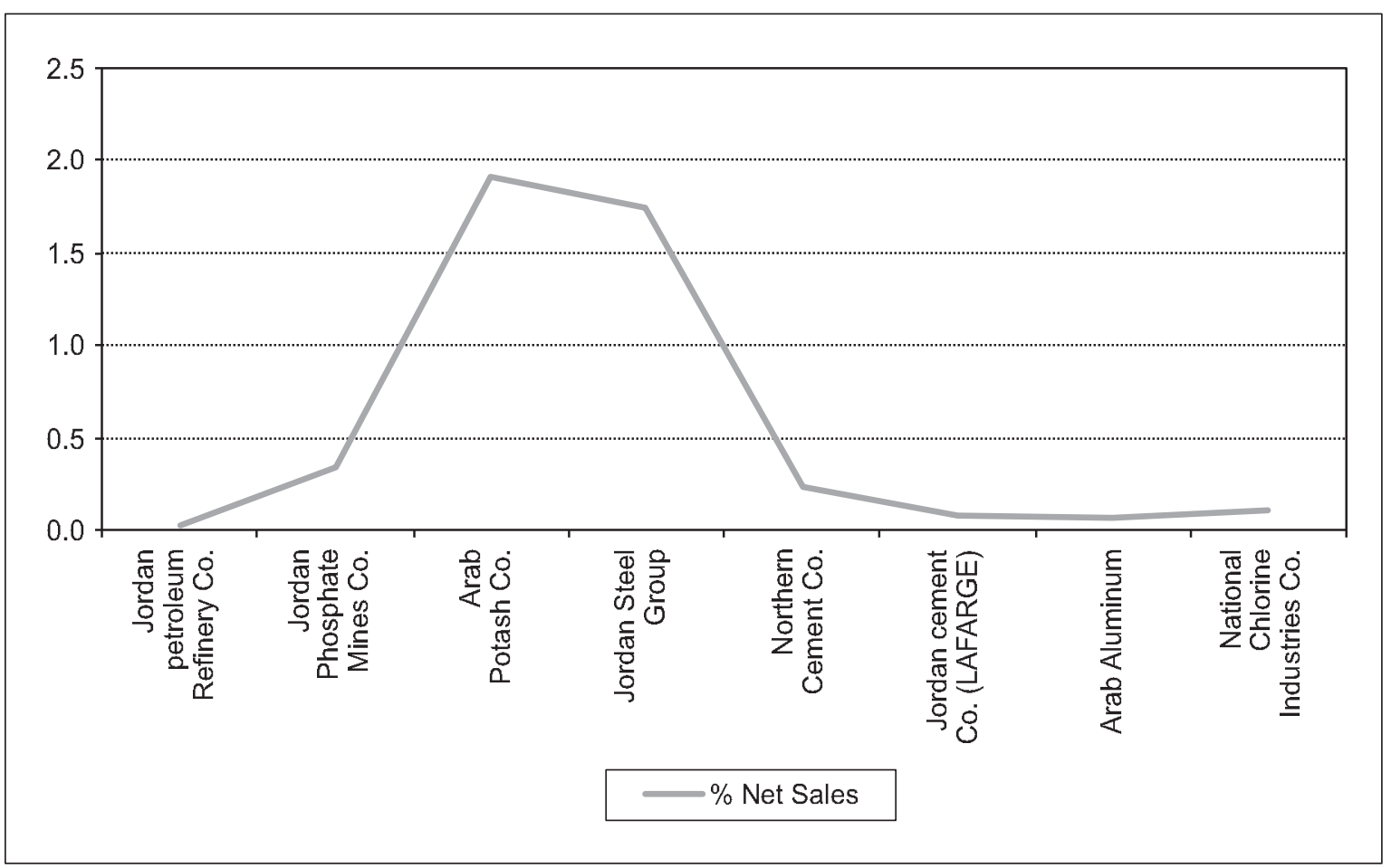

The donation's percentages calculated out of Net Sales varies between $0.06 \%$ and $1.92 \%$, which is almost close to the results obtained from the donation's percentages calculated out of Net Owner's Equity. Figure 3 illustrates the close relationship between the percentages calculated out of Net Owner's Equity and out of Net Sales. 
Figure 3.

\section{COMPARISON BETWEEN \% DONATION'S PERCENTAGES CALCULATED OUT OF NET SALES \&NET OWNER'S EQUITY}

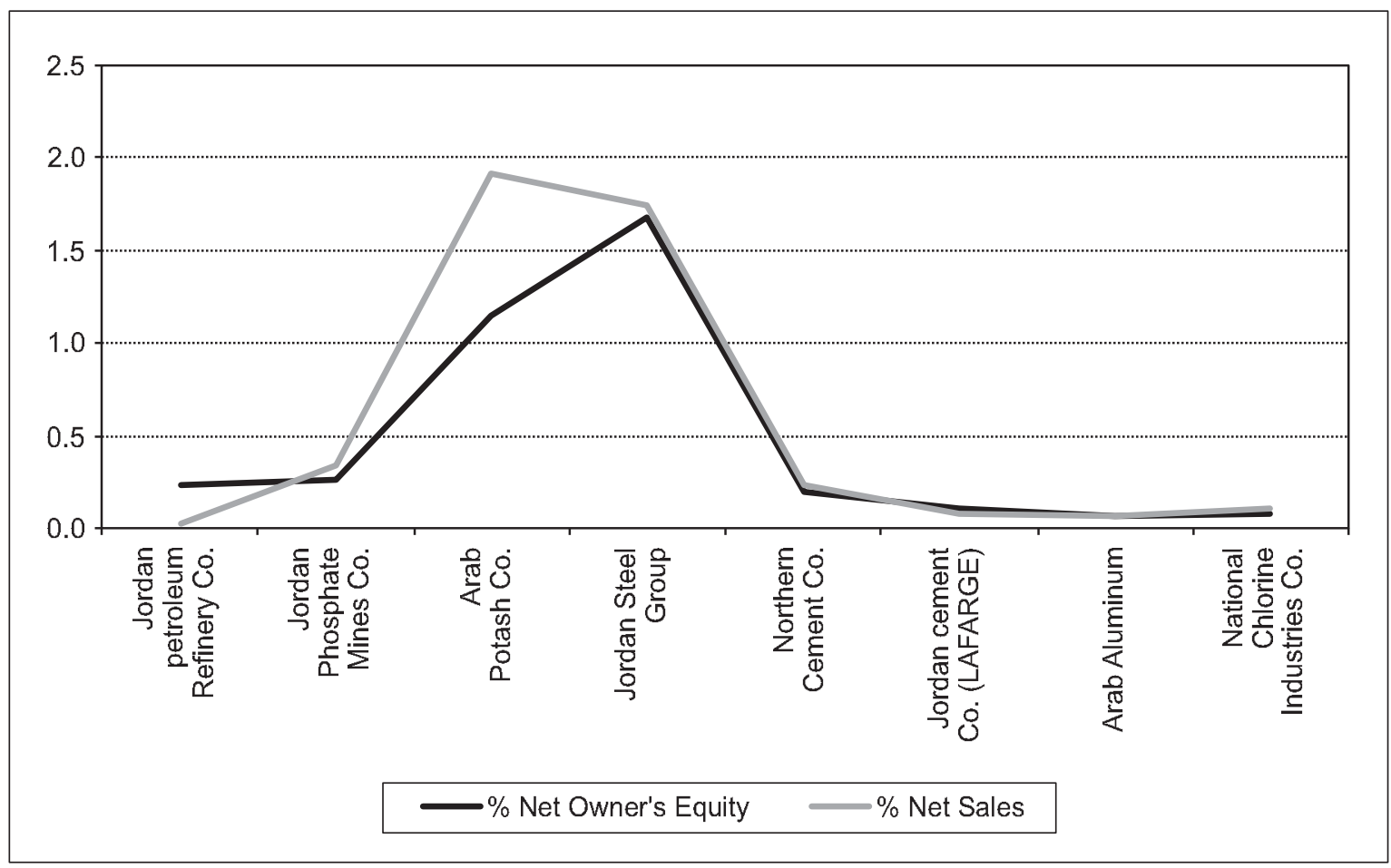

The previous results may be attributed to a common understanding between companies or board of directors in these companies saying that, the amount of compensation to be paid in form of corporate social responsibility should not exceed $2 \%$ of net owner's equity or net sales. We posit that these amounts paid are insignificant and akin to 'bread crumbs'. The question that arises is how to calculate the amount of compensation which should be paid as compensation to the society in which such firms exist? As mentioned earlier in the literature review section, there was a study lunched by The American Accounting Association which calls for reviewing the reasons that prevent accountants from providing the necessary information declaring the impacts of the project on the environment? It also calls for finding common bases or rules for measuring and presenting the social costs of environmental damage arising from project operations, and then calculating the proper amounts of compensation should be paid. 


\section{Recommendations}

- As the status of social reporting in Jordan is voluntary, so the government should work on enacting some rules and regulations which would make social reporting a compulsory task by the listed corporations.

- As there are many types and techniques of reporting, the Jordanian securities commission as a government regulatory party should work on establishing uniformity in disclosing social accounting reports, and the place of such disclosure should be clearly specified.

- Ministry of environment should be given a role in passing and approving the audited financial statements which should clearly disclose its social responsibility in the right and proper format.

\section{Suggestions for future research}

- As there are different regulations in each country, the findings of this study can't be generalized.

- The outcomes of this study are based on annual reports of sample companies, knowing that companies have other methods or mechanisms of reporting its social responsibility, so the future research should consider other forms of disclosure.

- This study focused on companies listed in Amman stock exchange market, knowing that there are many companies which are not listed in the market but nevertheless affect the subject of our research, so the future research should cover such type of companies.

\section{References:}

Ahmad, Nurulyasim Binti Ju, Rashid, Afzalur, Gow, Jeff, (2017). Board Independence and Corporate Social Responsibility (CSR) Reporting in Malaysia. AABFJ, 11(2), 62-85.

American Accounting Association Report of the committee on accounting for social performanceAccounting review 1971.

Bhimani, Alnoor, Silvola, Hanna, sivabalon, Prabhu, (2016). Voluntary Corporate Social Responsibility Reporting: A study of Early and late Reporter Motivation and Outcomes. Journal of Management Accounting Research, 28(2), 77-101 
Byrd, John, Hickman, Kent, Baker, Richard, Cohonier, Bruno, (2016). Corporate Social Responsibility Reporting in Controversial Industries. International Review of Accounting, Banking \& Finance, 8(2/3/4), 1-14.

Cheng, Suwina, Lin, Kenny Z., Wong, William, (2016). Corporate Social Responsibility Reporting and Firm Performance: Evidence from China. Springer: Journal of management \& Governance, 20:503-523. DOI 10.1007/s10997-015-9309-1.

Jahan, Noor Firdoos, (2010). Social Accounting \& Social Responsibility Reporting: An Overview. Vishwakarma Business Review, 70-78.

Mohammad Jizi, Rabih Nehme, Aly Salama, (2016). Do social responsibility disclosures show improvements on stock price?, Journal of Developing Areas, 50(2), 77-95.

Shabana, Kareem M. Ravlin, Elizabeth C., (2016). Corporate Social Responsibility as Substantive and Symbolic behavior: A Multilevel Theoretical Analysis. Business \& Society Review, 122(2), 297-327.

Wadhwa, Prakar, (2017). Non-Financial Reporting: Corporate Social Responsibility executives and Materiality. International Journal of Research in Commerce and management, 8(6), 54-56.

\section{SOCIJALNO RAČUNOVODSTVO I IZVJEŠĆIVANJE O DRUŠTVENOJ ODGOVORNOSTI U JORDANSKIM KORPORACIJAMA NA AMMANSKOJ BURZI}

Sažetak

Ovaj rad istražuje praksu socijalnog računovodstva i izvješćivanja o društvenoj odgovornosti u jordanskim korporacijama na ammanskoj burzi. S obzirom da aktivnosti korporacija imaju značajan utjecaj na društvo, one trebaju biti odgovorne spram okoline i članova društva u kojima djeluju. Kako bi se utvrdilo stanje socijalnog računovodstva i izvješćivanja, provedena je analiza godišnjih izvješća 30 slučajno odabranih jordanskih korporacija za 2016. godinu. Istraživanje je pokazalo kako 73\% korporacija u Jordanu iskazuju svoje društveno odgovorne aktivnosti u godišnjim izvješćima. Kako bi informirali o njihovoj predanosti društvenoj odgovornosti, 50\% tih korporacija koriste izvještaje menadžmenta, 36\% korporacija koristi izvješće o društvenoj odgovornosti poduzeća, a $14 \%$ koristi bilješke uz financijske izvještaje. S obzirom da postoje mnoge tehnike izvještavanja, zaključak je kako jordanska komisija za vrijednosne papire, kao regulatorno tijelo državne vlasti, treba raditi na uspostavljanju jedinistvenih izvještaja o socijalnom računovodstvu.

Ključne riječi: ammanska burza, društvena odgovornost, društveno odgovorno izvješčivanje, jordanske korporacije 